\title{
Characteristic temporal variability and trend of annual rainfall series in Port Harcourt Nigeria, a tropical coastal location
}

\author{
M. E. Agbor ${ }^{1}$, S. O. Udo ${ }^{1}$ and S. O. Amadi ${ }^{2 *}$ \\ ${ }^{1}$ Department of Physics, University of Calabar, Calabar, Nigeria. \\ 2Department of Physics, Geology \& Geophysics, Alex Ekwueme Federal University Ndufu - Alike, Ikwo, Nigeria. \\ ${ }^{*}$ Corresponding author. Email: solomonokeamadi@gmail.com
}

Copyright @ 2019 Agbor et al. This article remains permanently open access under the terms of the Creative Commons Attribution License 4.0, which permits unrestricted use, distribution, and reproduction in any medium, provided the original work is properly cited.

Received 3rd March, 2019; Accepted 2nd April, 2019

\begin{abstract}
Rainfall analysis over a locality provides useful information for sustainable water resources management over such an area. The paper is designed to examine the temporal variability of annual rainfall amount in Port Harcourt, Nigeria. Using monthly rainfall amount for a period of 41 years, Standardized Precipitation Index (SPI) and other statistical tools were used to evaluate anomalies in the annual rainfall amount for Port Harcourt, Nigeria during 1972 to 2012. Simple statistical techniques were used to evaluate the trend and rainfall variability index over the period of the study. The trend in rainfall series is statistically defined by the function $Y=2.180 x+2392$, indicating an increase of $2.180 \mathrm{~mm}$ per year. The year 1993 recorded the highest SPI value of +3.369 while the lowest SPI was -1.420 recorded in 1983 . The city witnessed sequences of distinct cycles of wet and dry spells with dominant dry spells. The SPI values present mild to severe anomalies from the normal. The Port Harcourt annual rainfall series requires effective monitoring in such a manner that timely warnings and swift response actions are provided in the run-up to the occurrence of those extreme events and their associated risks and damning consequences. These are necessary to guarantee effective risk reduction and management in the area.
\end{abstract}

Keywords: Drought, flood, Port Harcourt, rainfall, standardized precipitation index, trend, variability.

\section{INTRODUCTION}

Climate variability study is an essential ingredient for sustainable development strategy and planning as implied in numbers 1 and 2 of the Sustainable Development Goals (SDGs). In particular, rainfall climatology studies are vital for agriculture and related sectors, including proper water management strategy of a locality. This study is anchored on climate variability concept which presupposes that global, regional and local climates are prone to variations and fluctuations resulting from the dynamic meteorological variables influencing periodic weather manifestations world-wide. Rainfall is the major source of water. Water is a necessary staple that supports life. Water is needed for agricultural, domestic and industrial activities. It is a resource that requires adequate management, especially in the drought and flood prone areas of a region. Port
Harcourt is a coastal tropical location that adjoins the Atlantic Ocean and some regions in the study area are prone area to flooding.

Rainfall has a strong correlation with the ocean atmosphere interaction processes. The heat, moisture and momentum fluxes strongly influence the atmospheric and oceanic circulations. Significant changes in them influence regional circulations and rainfall patterns. The tropical and subtropical sea surface temperature anomalies (SSTA) induce anomalies in regional precipitation and demonstrate the importance of coupling in the ocean atmosphere interface. SSTA trigger variations in atmospheric circulation patterns. Consequently, they influence the behaviour of the large-scale weather systems that give rise to precipitation across regions. 
Some known teleconnections associated with the West African rainfall are South Atlantic SSTA and EI Nino Southern Oscillation (ENSO) phenomena (Camberlin et al., 2001).

In Nigeria, rainfall is the main source of water for a variety of uses, be it in the form of surface run-off into the rivers or subsurface recharge and storage. The patterns of atmospheric circulation in the tropics are particularly influenced by heat inputs from such sources as warm ocean surfaces (Lockwood, 1988). Other related heat sources such as high plateaus and equatorial rainforests have important bearing on tropical circulations (Nicholson et al., 1998). One of the resulting effects of these circulation patterns is that the West African rainfall patterns display both annual variations, and a marked link with some teleconnection phenomena (Nicholson, 1993).

In West Africa, years of dry and wet spells have been linked to inter - annual variability associated with ENSO phases (Camberlin et al., 2001). It has also been reported that Atlantic SSTA can influence regional precipitations with such effects as the intensification and weakening of the ENSO effects (Souza et al., 2005; Amorim et al., 2014). The combined effect of simultaneous occurrence of ENSO and South Atlantic SSTA has been investigated for some regions such as Northeast Brazil (Andreoly and Kayano, 2006; Kayano et al., 2009). ENSO events give rise to enhanced north easterlies and weakened south westerlies, bringing drought in West Africa close to the surface position of the Atlantic Inter Tropical Convergence Zone (ITCZ) in July to September rainfall. Positive correlation exists between tropical South Atlantic SSTA and July to September rainfall south of latitude $10^{\circ} \mathrm{N}$ in West Africa (Barry and Chorley, 1992). This correlation becomes more positive on the shores of the Gulf of Guinea, with the vanishing of the little dry season usually observed over West Africa around August. These variations also affect the position of ITCZ which is a great determinant of weather in Nigeria. The ITCZ has a north south oscillatory movement that dictates the Nigeria weather pattern. Strong positive South Atlantic SSTA brings about reduced temperature gradient towards the usually over-heated adjoining continent. This results in weakened south westerlies and a stagnation in the northward excursion of the ITCZ, causing torrential rains along the Gulf of Guinea. Hence, the variability of rainfall in the area is influenced by local variations and teleconnections, notably ENSO and South Atlantic SSTA. The combined effects of all these would amplify or inhibit rainfall anomalies depending on whether the resulting wind flow variations are favourable or otherwise to precipitation formation.

The study area has received a tremendous share of atmospheric pollution resulting from greenhouse gases emissions and aerosols accumulation. Large aerosols and greenhouse gases modify the amount of out-going longwave radiation by absorbing out-going long-wave radiation and re-emitting less energy at lower temperatures.
Sulphate and nitrate aerosols act as cloud condensation nuclei (CCN) and could enhance cloud-albedo effect or cloud-lifetime effect (Sanchez-Lorenzo et al., 2009). Both effects have the tendency of retarding the growth of rain drops which decreases precipitation formation. On the other hand, large aerosols (2.5 um) favour precipitation formation and are efficiently removed by precipitation (washout). These developments unravel the need for the review of Port Harcourt inter - annual rainfall variability.

Some rainfall analyses studies have been done across national and regional borders using a variety of methods such as Amadi et al. (2014), Ewona et al. (2014), Akinyemi et al. (2013), Ngongondo et al. (2011), Omogbai (2010), Longobardi and Villani (2009) and De Luis (2000). Port Harcourt and other coastal areas are expected to receive sufficient rainfall amount all the year round. However, NiMet (2008) observed an increase in annual rainfall in Port Harcourt in the range of 2 to $4 \mathrm{~mm}$ and a prognosticated tendency for drought in the Mangrove ecological zone of Nigeria where Port Harcourt belongs. Most studies on the subject within the climatic zone of the study area concentrated on evaluation and analysis of rainfall trends (Ewona et al., 2014; Udo-Inyang and Edem, 2012). Oloruntade et al. (2017) analyzed rainfall trends in the Niger-South Basin of Nigeria during 1948 to 2008. This basin is outside the ecological zone of the present study. Similar study is Oloruntade et al. (2018) that analyzed rainfall trend and variability over Onitsha which lies within the tropical rainforest zone. Ukhurebor and Abiodun (2018) observed dominant dry spell of $52.5 \%$ and wet spell of $47.5 \%$ with alternating downward and upward rainfall trends from 1978 to 2017 for South-South Nigeria including Port Harcourt. There is the need to study the rainfall variability of localities because climate information becomes more pertinent to the end users when the information provided is localized. Hence the present study is aimed at examining the inter-annual rainfall variability in Port Harcourt for the purposes of evaluating the trend and definite shortfalls or excesses in total annual rainfall and the possible resulting consequences. This study is necessary to authenticate the prognosticated tendency for drought in the Mangrove ecological zone of Nigeria as mooted by NiMet (2008). The sequences of dry and wet spells of rainfall series in the study area were defined and delimited to establish the occurrence of drought in the study area.

\section{MATERIALS AND METHOD}

\section{Study area}

Port Harcourt lies on longitude $6.57^{\circ} \mathrm{E}$, latitude $5.01^{\circ} \mathrm{N}$ and $18 \mathrm{~m}$ above sea level. It is located within the Mangrove swamp forest belt of Nigeria. It is the capital of Rivers State of Nigeria that is notable for her huge deposits of crude oil and plays host to many oil companies and allied industries. 


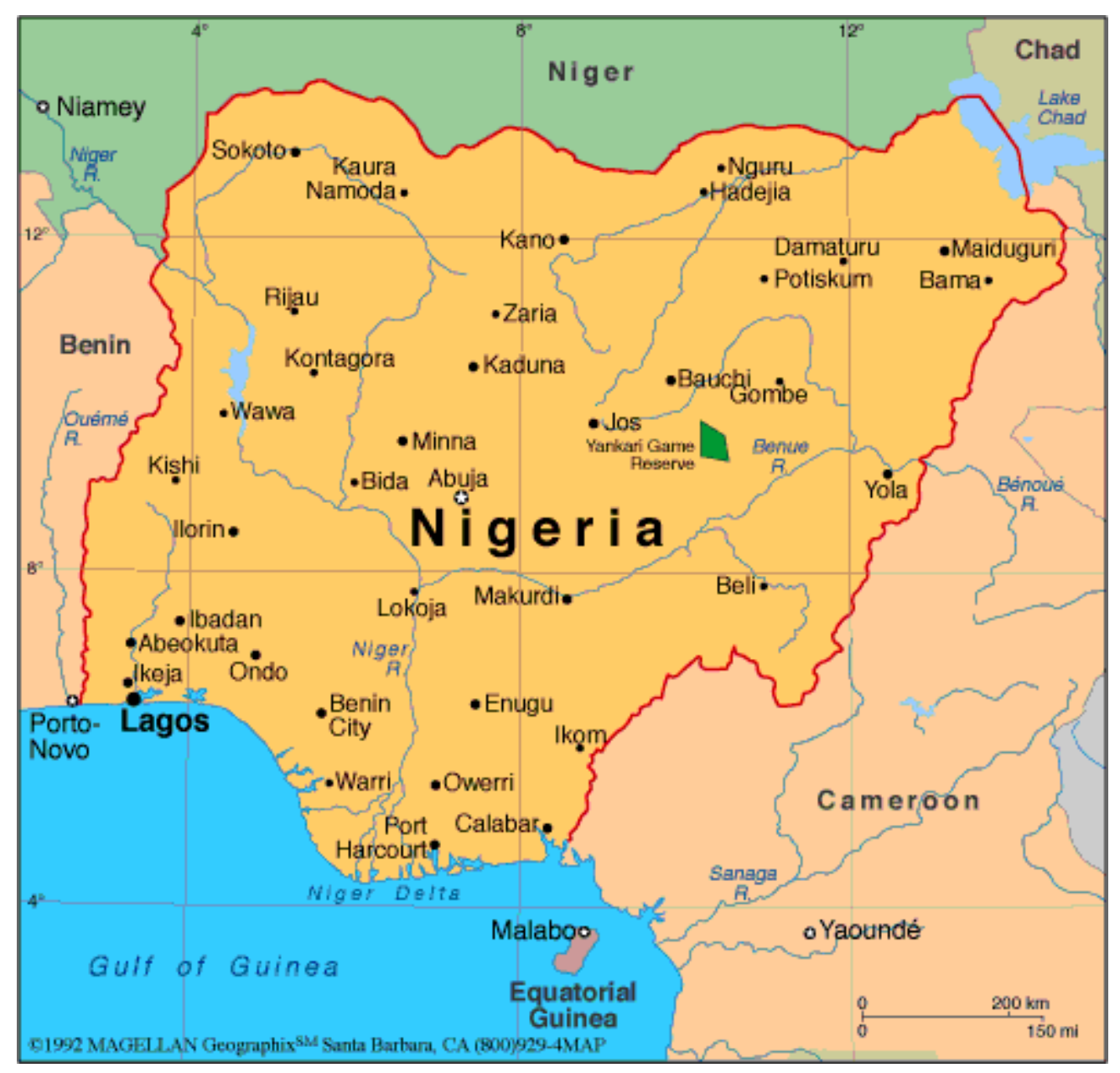

Figure 1. Map of Nigeria showing the location of Port Harcourt.

The study area plays host to almost all the oil companies operating in Nigeria in the up-stream, middle-stream and down-stream sectors on account of her huge oil deposits. The area has witnessed and continues to witness atmospheric variations prompted by the industrial activities. It has a record of lengthy and heavy rainy season and short dry season. The rainy season is usually from April to November. The total annual rainfall is in excess of $2000 \mathrm{~mm}$. Temperatures are relatively constant and average about 25 to $28^{\circ} \mathrm{C}$. The thick dusty Harmattan wind is not significantly noticed in the area. The dominant air masses are the tropical maritime air mass and the tropical continental air mass. These air masses meet at the ICTZ whose north - south migration determines the weather pattern over Nigeria. The State is sandwiched between Bayelsa and Akwa lbom States of Nigeria, both with large petroleum deposits. Figure 1 is the map of Nigeria showing the location of Port Harcourt.

\section{Data collection}

Total monthly rainfall data for 41 years (1972 to 2012) were obtained from the archives of the operational headquarters of The Nigerian Meteorological Agency, (NiMet), Oshodi Lagos, Nigeria but accessed through the Meteorological Department of Margaret Ekpo International Airport, Calabar, Nigeria. NiMet is a long-standing authority in meteorological services with standard equipment and skilled personnel. Hence the accessed data were of high grade.

\section{Methods}

The most popular rainfall variability index is standardized precipitation index (SPI) proposed by McKee et al. (1993). SPI is robust and versatile and has been adjudged the best climatic index for identification, severity quantification, duration and spatial extent of the droughts (Keyantash and Dracup, 2002). Table 1 shows the SPI categorization (McKee et al., 1993; 1995). However, Agnew (2000) proposed a categorization system based on probability values to quantify the severity of each dry spell as presented in Table 2. Furthermore, another drought index is the percentage of normal index, PNI, obtained by 
Table 1. SPI categories by McKee et al. (1993, 1995).

\begin{tabular}{ll}
\hline SPI values & Categories \\
\hline 0 to -0.99 & Mild drought \\
-1.0 to -1.49 & Moderate drought \\
-1.5 to -1.99 & Severe drought \\
$<-2.0$ & Extreme drought. \\
\hline
\end{tabular}

Table 2. Categorization by Agnew (2000).

\begin{tabular}{lcl}
\hline SPI & Probability & Category \\
\hline$>1.65$ & 0.05 & Very humid \\
$>1.28$ & 0.1 & Humid \\
$>0.84$ & 0.2 & Moderately humid \\
-0.84 to +0.84 & 0.6 & Normal \\
$<-0.84$ & 0.2 & Moderately dry \\
$<-1.28$ & 0.1 & Dry \\
$<-1.65$ & 0.05 & Very dry \\
\hline
\end{tabular}

dividing amount of precipitation for a particular period with the average and expressed as a percentage (Simsek and Cakmak, 2010). Table 3 is the drought index values based on PNI classification.

Monthly total rainfall data were aggregated to total annual rainfall for the analysis. Analyses of trends and fluctuations were executed using the least squares linear fitting and SPI. SPI values were evaluated using SPSS version 17 package. The SPI values were plotted against the years using Excel 2010 software. Regression analysis has been used in combination with other tools to analyze trends in climatic parameters in Nigeria (Amadi et al., 2014; Afangideh et al., 2010; Bibi et al., 2014) and across the globe (Durlo, 2006; Liu et al., 2006; Turkes et al., 2002; Gil-Alana 2008; Zhihua et al., 2013). The SPI is expressed as by McKee et al. (1993):

$X_{j}=\frac{\left|r_{j-r_{i}}\right|}{\sigma_{i}}$

Where: $X_{j}$ is normalized departure (Standardized Precipitation Index), $r_{j}$ is the annual total rainfall for the year $\mathrm{j}, r_{i}$ is the mean annual total rainfall for the station $\mathrm{i}$ and $\sigma_{i}$ is the standard deviation of station i's annual rainfall.

The SPI is basically obtained by dividing the deviation of precipitation from the mean for a particular period of time with the standard deviation. The PNI index as defined by Simsek and Cakmak (2010):

$\mathrm{PNI}=\left(\mathrm{p}_{\left.\mathrm{a} / \mathrm{p}_{\mathrm{i}}\right)}\right) 100$

Where: $p_{a}=$ actual precipitation in $\mathrm{mm}$ and $p_{i}=$ average precipitation in $\mathrm{mm}$.
Drought magnitude, $M_{j}$ as expressed by Sirdas and Sen (2003):

$M_{j=} \sum_{i=1}^{n}\left|x_{o-X_{i}}\right|$

Where: $x_{o}=$ the standardized truncation level for each drought description, $x_{i}=$ the standardized precipitation index and $\mathrm{n}=$ number of deficits during the drought period.

The drought intensity, $I_{j}$ of the $j^{\text {th }}$ dry spell is expressed as the ratio of drought magnitude to drought duration (Sirdas and Sen, 2003):

$I_{j}=\frac{M j}{L j}$

where $L_{j}$ is the drought duration.

\section{RESULTS AND DISCUSSION}

Table 4 shows the SPI values of the individual years and the intensities of the various spells during the period. The year 1993 witnessed the highest recorded annual rainfall amount of $3911.7 \mathrm{~mm}$ and SPI value of +3.37 . The year 1983 witnessed the lowest recorded annual rainfall amount of $1816.4 \mathrm{~mm}$ followed by the year 1973 with annual rainfall of $1837.4 \mathrm{~mm}$ with SPI values of -1.42 and -1.37 , respectively. The ENSO phases of 1973 and 1983 are most likely responsible for the very low annual rainfall amount in those years because ENSO has negative correlation with West African rainfall (Kiladis and Diaz, 1989; Camberlin et al., 2001), which are clearly made manifest during intense ENSO episodes. It is on record that these two years witnessed the most intense ENSO events over West Africa in the 20th century (McGregor and Nieuwolt, 1998). This is further manifested in the result of Oloruntade et al. (2018) which observed that the year 1983 was the driest with variability index of -2.38 between 1971 and 2008 rainfall over Onitsha. The table further indicates that the dry spell of 1988 to 1992 was the most intense and most prolonged while the wet spell of 1979 to 1982 was the most intense and most prolonged. The area exhibits rainfall cycles with mild to severe anomalies relative to the normal. These observations are perhaps clear demonstrations of the effect of prevailing teleconnection phenomena over the area such as South Atlantic sea surface temperature anomalies and ENSO.

Figure 2 is the least squares regression composite graph. It depicts the overall trend line (black line) and the five years moving average curve (red line). The actual inter-annual variability curve is represented by the blue line. The regression line equation indicates a non significant upward trend of $2.18 \mathrm{~mm}$ per year with a coefficient of determination of 0.003 , indicating very weak temporal correlation. This implies that the annual rate of increase in rainfall in the area is inconsequential. This 
Table 3. Drought index values based on PNI classification.

\begin{tabular}{lccc}
\hline Normal and above & Slight drought & Moderate drought & Severe drought \\
\hline (No risk) & (Start monitoring) & (Warning) & (Emergency) \\
$>75 \%$ & 65 to $75 \%$ & 55 to $65 \%$ & $<55 \%$ \\
\hline
\end{tabular}

Table 4. Port Harcourt annual rainfall standardized anomaly index.

\begin{tabular}{|c|c|c|c|}
\hline Year & Annual Rainfall(mm) & SPI & Drought Intensity \\
\hline 1972 & 2225.0 & -0.4867 & -0.797 \\
\hline 1973 & 1837.4 & -1.3727 & \\
\hline 1974 & 2204.6 & -0.5333 & \\
\hline 1975 & 2526.9 & 0.2034 & \\
\hline 1976 & 2328.3 & -0.2505 & -0.372 \\
\hline 1977 & 2235.5 & -0.4627 & \\
\hline 1978 & 2261.9 & -0.4023 & \\
\hline 1979 & 3338.8 & 2.0594 & 1.5099 \\
\hline 1980 & 3328.0 & 2.0347 & \\
\hline 1981 & 2909.5 & 1.0780 & \\
\hline 1982 & 2817.5 & 0.8677 & \\
\hline 1983 & 1816.4 & -1.4202 & -0.7044 \\
\hline 1984 & 2362.5 & -0.1724 & \\
\hline 1985 & 2206.8 & -0.5283 & \\
\hline 1986 & 2133.5 & -0.6959 & \\
\hline 1987 & 2763.9 & 0.7452 & \\
\hline 1988 & 2333.6 & -0.2384 & -0.8754 \\
\hline 1989 & 1865.5 & -1.3085 & \\
\hline 1990 & 2073.3 & -0.8335 & \\
\hline 1991 & 2029.9 & -0.9327 & \\
\hline 1992 & 1972.4 & -1.0641 & \\
\hline 1993 & 3911.7 & 3.3691 & \\
\hline 1994 & 2370.0 & -0.1552 & \\
\hline 1995 & 2490.9 & 0.1212 & \\
\hline 1996 & 2419.5 & -0.0421 & -0.1636 \\
\hline 1997 & 2313.2 & -0.2851 & \\
\hline 1998 & 2567.0 & 0.2951 & 0.2181 \\
\hline 1999 & 2499.6 & 0.1410 & \\
\hline 2000 & 1994.3 & -1.0141 & -0.8361 \\
\hline 2001 & 2150.0 & -0.6581 & \\
\hline 2002 & 2496.8 & 0.1346 & 0.41 \\
\hline 2003 & 2738.0 & 0.6860 & \\
\hline 2004 & 1989.5 & -1.0250 & \\
\hline 2005 & 2607.7 & 0.3881 & 0.854 \\
\hline 2006 & 2960.8 & 1.1953 & \\
\hline 2007 & 2866.0 & 0.9786 & \\
\hline 2008 & 2049.9 & -0.8870 & \\
\hline 2009 & 2842.2 & 0.9242 & 0.548 \\
\hline 2010 & 2513.2 & 0.1721 & \\
\hline 2011 & 2317.4 & -0.2755 & -0.3124 \\
\hline 2012 & 2285.1 & -0.3493 & \\
\hline
\end{tabular}




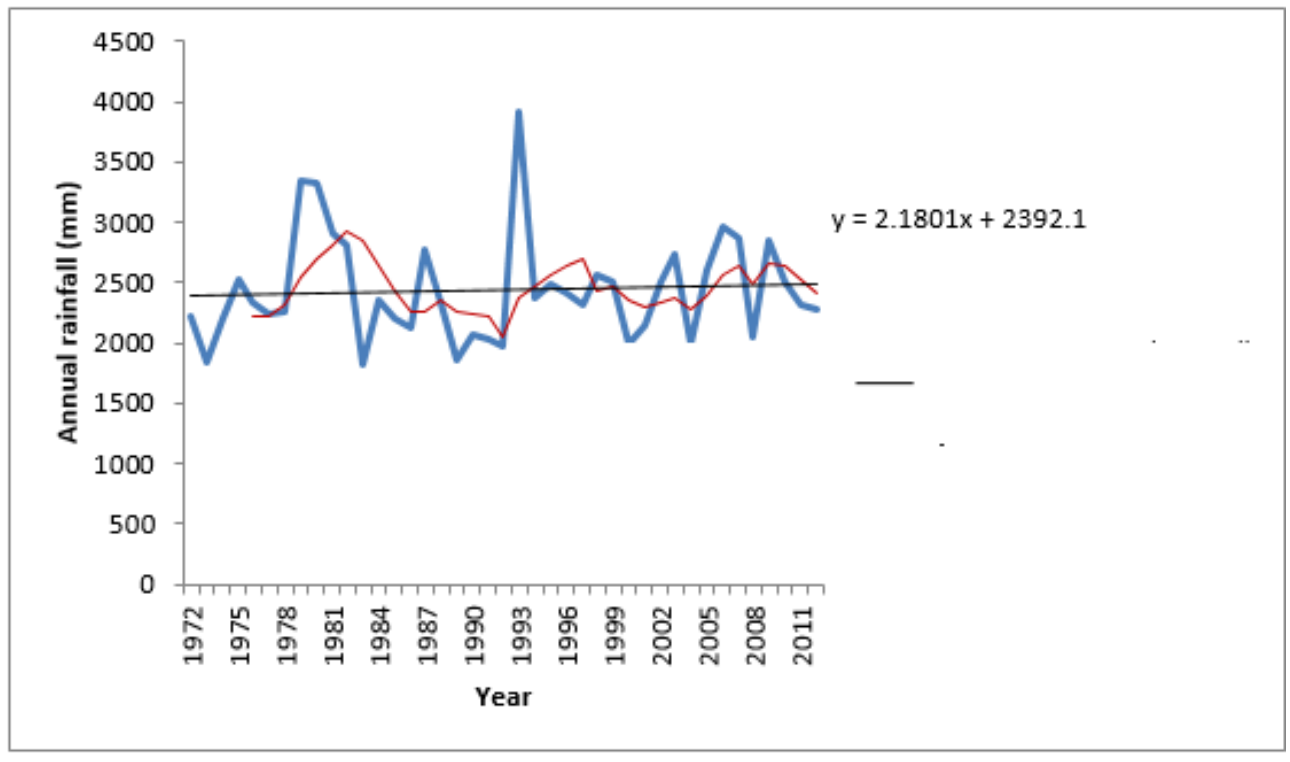

Figure 2. Least squares regression composite graph.

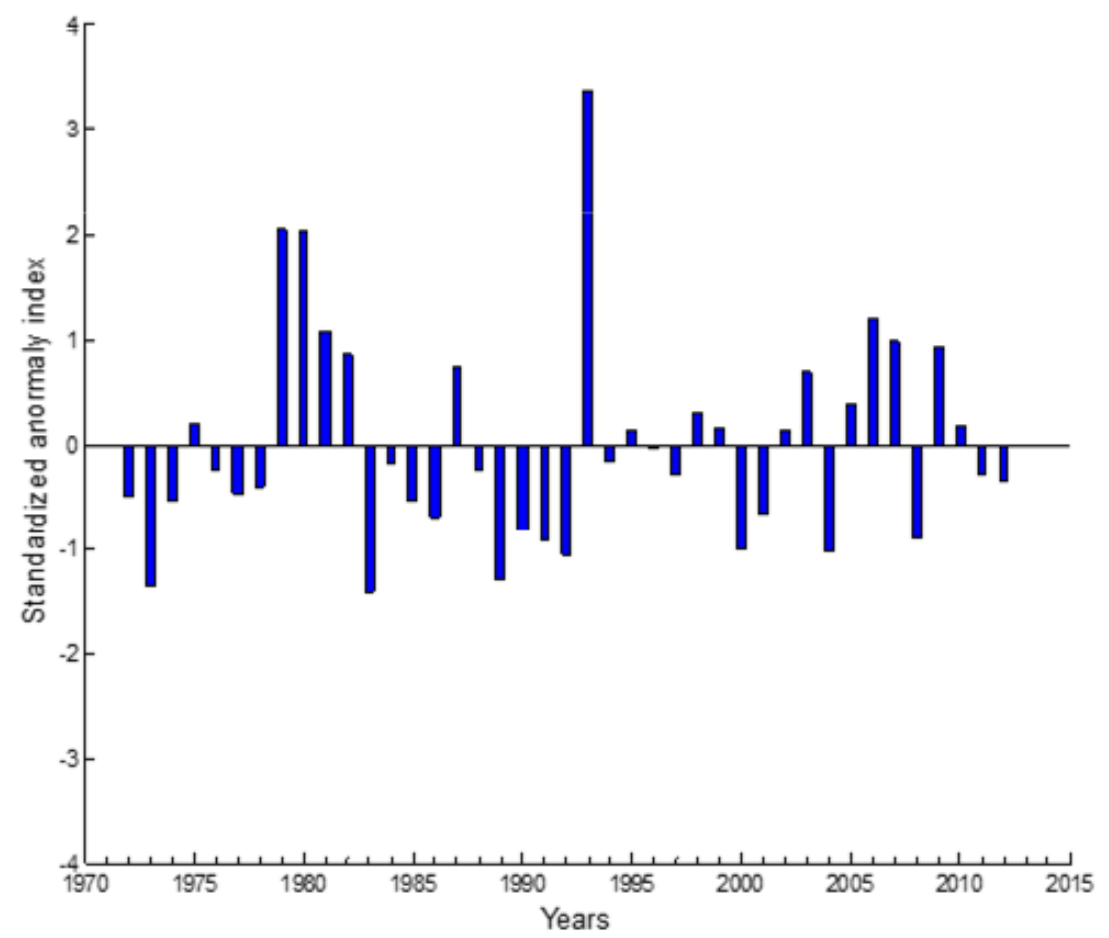

Figure 3. Inter-annual rainfall variability index plots.

trend result is consistent with Ewona et al. (2014) that observed non-significant upward trend in Port Harcourt rainfall during 1978 to 2007 . The result is also in agreement with the non-significant trends in rainfall in three stations of Uyo, Eket and Obotakara in the neighbouring Akwa lbom State which is located within the Mangrove agro-ecological zone of Nigeria as displayed by
Udo-Inyang and Edem (2012). The result equally has consonance with Oloruntade et al. (2017).

Figure 3 is the inter-annual rainfall variability index plot. It is shown that years with negative SPI values (drought years) dominate the record, comprising $58.54 \%$ of the period under analysis. These observations point to the fact that the study area is characterized by high rainfall 


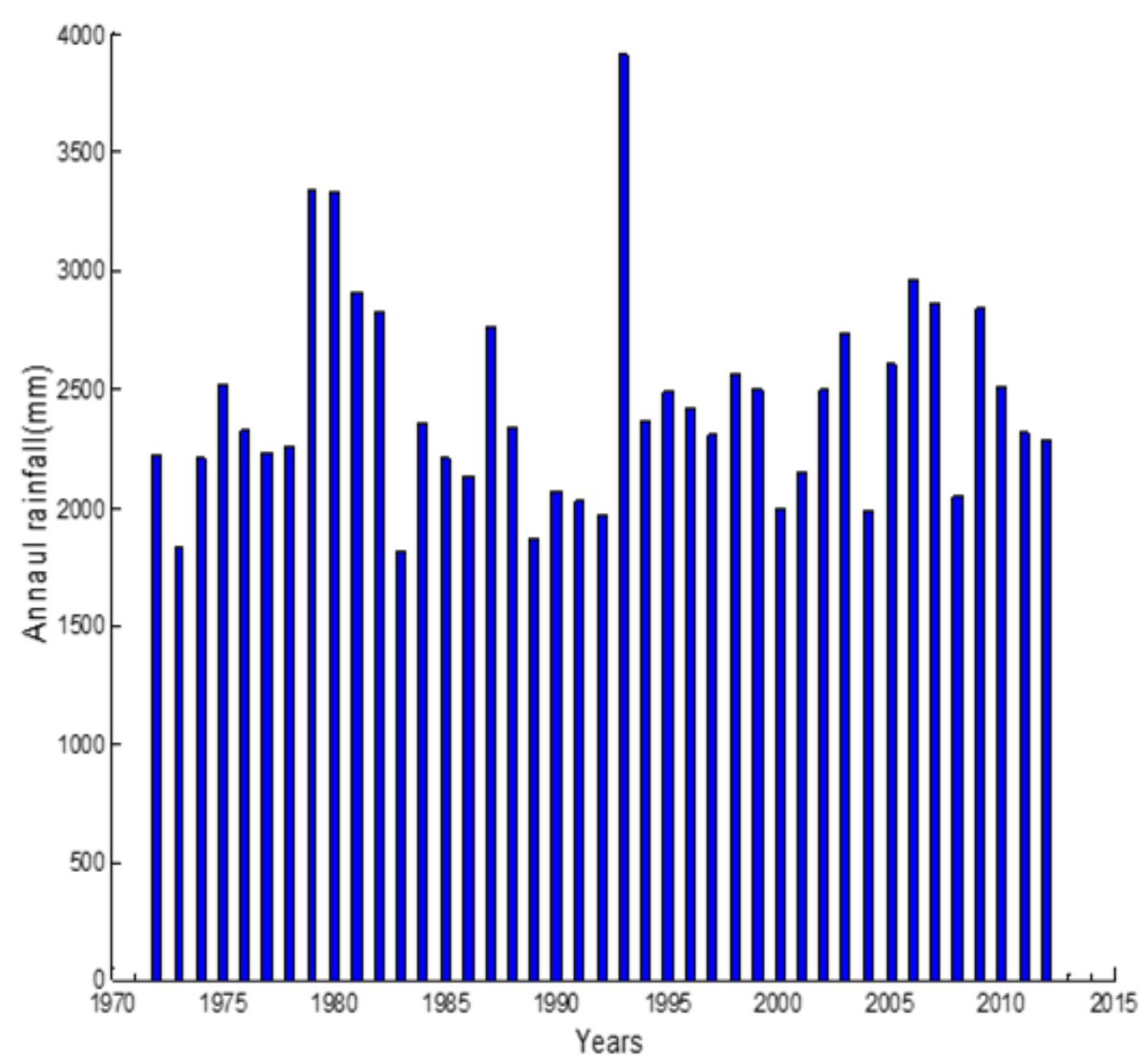

Figure 4. Comparative bar chart of annual rainfall amount.

variability to the level that the potential risks cannot be ignored. There is the need for monitoring that could engender swift response to reduce risk or avert danger associated with rainfall variability. Figure 4 is the comparative bar chart depicting elaborate year to year fluctuations. The findings in this study are in agreement with NiMet (2008) and Ukhurebor and Abiodun (2018) for the existence of rainfall variability in South-South Nigeria. These results have some far-reaching implications. Changing and erratic rainfall patterns make it difficult for planning of farming operations, with reduced yields and absolute crop failure as the possible resulting consequences. Extreme rainfall variability in this area has a range of consequential effects: flooding and water logging, inundation and erosion of farmlands, leaching, surface run-offs, reduced soil fertility and drought (NiMet, 2011). The cumulative effect of all these is decreased agricultural productivity and other socio-economic effects on bioclimatology. There is need to recognize the existence of high rainfall variability in Port Harcourt which must be acknowledged as an integral component of sustainable development in the area. The inhabitants of the area need to be sensitized for prompt adaptation measures. This calls for articulated actions geared towards initiating and sustaining improved adaptive capacity to mitigate against the associated risks because of their influence on rain-fed agriculture and other aspects of human support systems.

\section{Conclusion and recommendations}

Rainfall variability index has been used to define and delimit the sequences of dry and wet spells in Port Harcourt total annual rainfall series. The results demonstrate that the area experienced sequences of distinct cycles of wet and dry spells of which the dry spells were dominant. The SPI values portray mild to severe rainfall anomalies relative to the normal which are strong indications of high rainfall variability. The study has authenticated the existence of dry spell in Port Harcourt inter-annual rainfall climatology and lends support to the prognosticated tendency for drought in the agro-ecological zone of the study area according to NiMet (2008). The cycles are most likely connected with local atmospheric variations coupled with teleconnections involving ENSO and South Atlantic SST anomalies. The paper explored the need to recognize the existence of high annual rainfall variability in the area and acknowledge it as an integral component of sustainable development. This calls for articulated actions geared towards initiating and sustaining improved adaptive capacity to minimize the associated 
risks.

It is recommended that provisions be made for early warnings and productive meteorological forecasts. Programmes that would facilitate integrated and sustainable improvement and extension of water supply and management of infrastructure are inevitable. Development of dynamic farming system and introduction of drought-resistant variety crops is also a requirement. Furthermore, since fishing is a leading occupation in the area, there is the need for the enhancement of artisanal fisheries and sustainable aquaculture.

\section{CONFLICT OF INTEREST}

The authors declare that they have no conflict of interest.

\section{REFERENCES}

Afangideh, A. I., Okpiliya, F. E., \& eja, E. I. (2010). A preliminary investigation into the annual rainfall trends and patterns for selected towns in parts of south Eastern Nigeria. Journal of Sustainable Development, 3(3), 275-282.

Agnew, C. T. (2000). Using SPI to identify drought. Drought Network News, 12, 6-12.

Akinyemi, O., Ayeni, O. A., Faweya, O. D., \& Ibraheem, A. G. (2013). Statistical study of monthly rainfall patterns in Ekiti State, Nigeria. International Journal of Pure and Applied Sciences and Technology, 15(2), 1-7.

Amadi, S. O., Udo, S. O., \& Ewona, I. O. (2014). Spatio temporal variations of monthly rainfall total in Nigeria for the period 1950 - 2012. International Journal of Pure and Applied Physics, 10(1), 75-93.

Amorim, A. C. B., Chaves, R. R., \& Silva, C. M. S. (2014). Influence of the tropical Atlantic Ocean's sea surface temperature in the eastern northeast Brazil precipitation. Atmospheric and Climate Sciences, 4(5), 874-883.

Andreoly, R. V., \& Kayano, M. T. (2006). Tropical Pacific and South Atlantic effects on rainfall variability over northeastern Brazil. International Journal of Climatology, 26(13), 1895-1912.

Barry, R. G. \& Chorley, R. J. (1992). Atmosphere, Weather and Climate, 6th edn, London, Routledge, Pp. 25-259.

Bibi, U. M., Kaduk, J. \& Balzter, H. (2014). Spatial-temporal variations of rainfall in Northern Nigeria. Climate, 2(3), 206222.

Camberlin, P., Janicot, S., \& Poccard, I. (2001). Seasonality and atmospheric dynamics of the teleconnection between African rainfall and tropical sea surface temperature: Atlantic Vs ENSO. International Journal of Climatology, 21(8), 973-1005.

De Luis, M., Raventos, J., Gonzalez - Hidalgo, J. C., Sanchez, J. R., \& Cortina, J. (2000). Spatial analysis of rainfall trends in the region of Valencia, East Spain. International Journal of Climatology, 20(12), 1451-1469.

Durlo, G. (2006). Multiannual variations of effective sunshine duration in Beskid Sadecki Mountains. Electronic Journal of Polish Agricultural Universities, 9(4), 12p.

Ewona, I. O., Osang, J. E., \& Udo, S. O. (2014). Trend analysis of rainfall pattern in Nigeria using regression parameters. International Journal of Technology Enhancement and Engineering Research, 2(5), 129-133.

Gil-Alana, L. A. (2008). Warming break trends and fractional integration in the northern, southern and global temperature anomaly series. Journal of Atmospheric and Oceanic Technology, 25(4), 570 - 578.

Kayano, M. T., Oliviera, C. P., \& Andreoli, R. V. (2009). Interannual relations between south American rainfall and tropical sea surface temperature anomalies before and after 1976. International Journal of Climatology, 29(10), 1439-1448.

Keyantash, J. \& Dracup, J. (2002). The quantification of drought: an evaluation of drought indices. Bulletin of the American Meteorological Society, 83(8), 1167-1180.

Kiladis, G. N., \& Diaz, H. F. (1989). Global climate anomalies associated with extremes in the Southern Oscillation. Journal of Climate, 2(9), 1069-1090.

Liu, X., Yin, Z., Shao, X., \& Qin, N. (2006). Temporal trends and variability of daily maximum and minimum extreme temperature events and growing season length over the eastern and central Tibetan Plateau, durind 1961 - 2003. Journal of Geophysical Research, 111 (D19109), 19p.

Lockwood, J. G. (1988). Climate and climate variability in semiarid regions at low latitudes. In: Parry, M. L., Carter, T. R., \& Konijn (eds), The impact of climate variations on agriculture: assessment in semi-arid region. Kluner Academic Publishers, Dordrecht.

Longobardi, A., \& Villani, P. (2009). Trend analysis of annual and seasonal rainfall time series in the Mediterranean area. International journal of Climatology, 30(10), 1538-1546.

McGregor, G. R. \& Nieuwolt, S. (1998). Tropical Climatology, 2nd edn, John Wiley and Sons Ltd, England, p. 103.

McKee, T. B., Doesken, N. J., \& Kleist, J. (1993). The relationship of drought frequency and duration to time scales. In: 8th Conference on Applied Climatology, 17 - 22 January, Anaheim, California, U. S. A., Am. Met. Soc., Pp. 179-184.

McKee, T. B., Doesken, N. J., \& Kleist, J. (1995). Drought monitoring with multiple time scales. In: Preprints, 9th Conference on Applied Climatology, Dallas, Texas, U.S.A.

Ngongondo, C., Xu, C., \& Gottschalk, L. (2011). Evaluation of spatial and temporal characteristics of rainfall in Malawi: a case of data scarce region. Theoretical and Applied Climatology, 106(1-2), 79-93,

Nicholson, S. E. (1993). An overview of African rainfall fluctuations of the last decade. Journal of climate, 6(7), 14631466.

Nicholson, S. E., Tucker, C. J., \& Ba, M. B. (1998). Desertification, drought, and surface vegetation: An example from the West African Sahel. Bulletin of the American Meteorological Society, 79(5), 815-830.

NiMet (2008). Nigerian Climate Review Bulletin 2007. The Nigerian Meteorological Agency, February 2008, NiMet No: 001.

NiMet (2011). Nigeria Climate Review Bulletin 2010. http://www.nimetng.org.

Oloruntade, A. J., Mogaji, K. O., \& Imoukhuede, O. B. (2018). Rainfall trend and variability over Onitsha, Nigeria. Ruhuna Journal of Science, 9(2), 127-139.

Oloruntade, A. J., Mohammad, T. A., \& Aimrun, W. (2017). Rainfall trends in the Niger-South Basin, Nigeria, 1948-2008. Pertanika J. Sci \& Technol. 25(2), 479-496.

Omogbai, B. E. (2010). An empirical prediction of seasonal rainfall in Nigeria. Journal of Human Ecology, 32(1), 23-27.

Sanchez-Lorenzo, A., Calbo, J., Brenetti, M., \& Daser, C. (2009). Dimming/brightening over the Iberian Peninsula: trends in sunshine duration and cloud cover and their relations with atmospheric circulation. Journal of Geophysical Research, 114, D00D09. 
Simsek, O., \& Cakmak, B. (2010). Drought analysis of 2007 2008 agricultural year of Turkey. Journal of Tekirdag Agricultural Faculty, 7(3), 99-109.

Sirdas, S., \& Sen, Z. (2003). Spatio - temporal drought analysis in the Trakya region, Turkey. Hydrological Sciences Journal, 48(5), 809-820.

Souza, E. B., Kayano, M. T., \& Ambbrizzi, T. (2005). Intraseasonal and submonthly variability within autmn rainy regime over the eastern Amazon/northeast Brazil and associated mehanisms. Theoretical and Applied Climatology, 81, 177-191.

Turkes, M., Sumer, U. M., \& Demir, I. (2002). Re-evaluation of trends and changes in mean, maximum and minimum temperatures of Turkey for the period 1929 - 1999. International Journal of Climatology, 22, 947-977.
Udo-Inyang, U. C., \& Edem, I. D. (2012). Analysis of rainfall trends in Akwa Ibom State, Nigeria. Journal of Environment and Earth Sciences, 2(8), 60-70.

Ukhurebor, K. E., \& Abiodun, I. C. (2018). Variation in annual rainfall data of forty years (1978-2017) for South-South, Nigeria. Journal of Applied Sciences and Environmental Management, 22(4), 511-518.

Zhihua, Z., Rui, L., Hui, Q., Jie, C., \& Xuedi, Z. (2013). Analysis of rainfall variation over the past 55 years in Guyuan City, China. Journal of Environmental Science, Computer Science and Engineering Technology, 2(3), 640-549. 